\title{
Upgrading Status of Right to Builds (HGB) Above The Right Management (HPL) Perumnas to Become Ownership Right (HM) (Case Study at Korpri Housing Bangetayu Wetan \\ Semarang)
}

\author{
Dian Yunanti Yakob Udi ${ }^{1}$ and Titin Prialianti ${ }^{2}$
}

Abstract. In order to facilitate the middle to lower economic level people to have a decent housing, the government established Perumnas. Citizens wishing to improve their land title to HM (Ownership Right) on residential houses purchased from the Right to Use (HGB). This process must meet the prescribed requirements. The research method used was sociological juridical approach with analytical descriptive research specification, while the data analysis method used was descriptive qualitative. Based on the results of study in Korpri Housing Bangetayu Wetan Semarang and Land Office of Semarang City, it can be concluded that the procedure for submission of HGB to HM, the applicant has to visit the Land Office of Semarang City and complete some administrative requirements in the form of filling registration form, ID Card, IMB, HPL Holders Recommendation Perumnas, SPPT PBB of the current year, land ownership statement not more than 5 fields, and power of attorney if the application is authorized. Some obstacles in the application of the upgrade from SHGB on HPL Perumnas land become SHM are some people do not know or less understand about the procedure and requirement to upgrade their right, so that they give authorized to Notary/PPAT (Land Deed Officials), effort in IMB, the house is used as houseshop instead of residence. The way to solve it is by conducting further socialization to the community through BPN (National Land Agency) service, Notary/PPAT and physical inspection of residential houses for which the rights are requested.

Keywords: Housing; Perumnas; Right to Manage; Ownership Right; Right to Builds.

\section{Introduction}

The need to interact with one another is a human social character. The interaction is used as an intermediary to meet the need for adequate clothing, food, shelter, and other necessities, including the need for housing and settlements that are shelter to protect individual's humans from the weather as well as other distractions. ${ }^{3}$

The house is the primary human need after food, therefore for the sake of assuring the status of residential ownership for Indonesian citizens, the government needs to guarantee the continuity of the right to the land where the dwelling house located ${ }^{4}$. The obstacles are not all citizens with low economic levels can have adequate housing. As a solution, National Housing (PERUMNAS) is established, a State-Owned Enterprises

\footnotetext{
${ }^{1}$ Students of Master Program (S2) in Notary Faculty of Law Universitas Islam Sultan Agung email yunantidian94@gmail.com

2 Students of Master of Law, Faculty of Law, Universitas Islam Sultan Agung email prialianti@gmail.com

3 Jarot Widya Muliawan 2015 Pemberian Hak Milik Untuk Rumah Tinggal Sebuah Kajian Normatif Untuk Keadilan Bagi Masyarakat Buku Litera Yogyakarta p. 1

${ }^{4}$ KMNA/KBPN Nomor 6 Tahun 1998 tentang Pemberian Hak Milik Atas Tanah Untuk Rumah Tinggal
} 
(SOE) in the form of Public Corporation (PERUM) where the whole shares owned by the Government ${ }^{5}$. Until now, Perumnas has always appeared and acted as a pioneer in providing housing and settlements for low-income middle-income people. ${ }^{6}$

Perumnas was first established by Government Regulation No. 29 of 1974 which was later amended by Government Regulation No. 12 of 1988, and was last amended by Government Regulation No. 15 of 2004 concerning Public Corporation (PERUM) National Housing Development on May 10, 2004. ${ }^{7}$

\section{Vision of Perumnas}

"Become the Most Trusted Settlement and Housing Developer in Indonesia".8

\section{Mission Perumnas ${ }^{9}$}

- Developing residential and value-added housing for customer satisfaction

- Improving the professionalism, empowerment and welfare of employees

- Maximizing value for shareholders and other stakeholders

- Optimizing synergy with partners, government, SOEs and other agencies

- Increasing positive contribution to society and environment

Housing and settlements have a very strategic role, one of them as a manifestation of the true national development is the development of the Indonesian people as a whole, as the sound of Article 27 paragraph (2) of the 1945 Constitution of the Republic of Indonesia has guaranteed every citizen to work and a decent livelihood for humanity. ${ }_{-}{ }^{10}$

Cited from Kompas.com, the 'Program One Million House' is famous reported today is the government's efforts to encourage the provision of housing for the community. The target of building one million units per year has not yet been achieved, but government efforts must be supported as home needs also upgrade every year. ${ }^{11}$

Based on data from the Ministry of Public Works and People's Housing (PUPR), the house needs per year is 800,000 to one million units. Khalawi Abdul Hamid said, "We encourage developers (developers), local governments, communities, and banking to support this One Million House Program". ${ }^{12}$

The Ministry of PUPR (Public Works and Housing) continues to coordinate with relevant ministries / agencies to encourage the ease of licensing of housing development in the regions. In addition, the pattern of Cooperation of Government and Business Entities (KPBU) is being pursued so that the role of the private sector in the fulfillment of housing upgrades. "It could be private use of government-owned land for housing

\footnotetext{
${ }^{5}$ Perumnas.co.id Sejarah PERUMNAS http://www.perumnas.co.id/sejarah-perumnas/ accessed 25 April 2018 at 12.30

${ }^{6}$ Ibid.

${ }^{7}$ Ibid.

${ }^{8}$ Ibid.

${ }^{9}$ Ibid.

${ }^{10}$ Jarot Widya Muliawan Op. Cit. p. 2

${ }^{11}$ Properti.kompas.com Pemerintah Gandeng Pengembang Wujudkan Satu Juta Rumah Untuk Rakyat https://properti.kompas.com/read/2018/04/21/200833821/pemerintah-gandengpengembang-wujudkan-satu-juta-rumah-untuk-rakyat accessed on 02 May 2018 at 01.23

${ }^{12}$ Ibid.
} 
construction, or it could be a purely built private sector and government support through infrastructure development," Khalawi said. ${ }^{13}$

The chairman of Real Estate Indonesia, Soelaeman Soemawinata, said that the developers who are members of the association REI ready to support the new city development planned by the government. ${ }^{14}$

However, the granting of Right to Manage (HPL) in its development sometimes causes a lot of bias, so the impact is less good.

"As stated by the President Director of Perum Perumnas, there are constraints on blocking of land parcels and on the strata title and the extension of its Hak Guna Bangunan which is above HPL. National Land Agency of the Republic of Indonesia supports and will conduct studies to find solutions to the problems faced Perum Perumnas, "said Hendarman Supandji while serving as KBPN RI in $2014 .{ }^{15}$

If a person purchases a house in one of the developer's estate, then the status of the land is a Right to Build (hereinafter called HGB) which is the right to establish and own a building not owning it within 30 years and can be extended for a maximum period of 20 years ${ }^{16}$. This is because the developer cannot own the Certificate of Ownership (SHM) for the residence it develops. Generally, the developer in housing is a private business entity or limited liability company, while those who are entitled to own the land with Ownership Right status (hereinafter called HM) are Indonesian citizens single and certain social legal entities. Therefore, when the developer obtains the land from the residents who will be used as residential area with HM status, then the status of the land must first be released into state land which then then reapplied into HGB on behalf of the developer concerned. There is a developer when buying a home from a person and promise to upgrade the status of the land over the house, but there are also those who only give the SHGB directly without offering the upgrading.

It is undeniable that the fulfillment of occupancy will be more meaningful if it is obtained with the status of HM (Ownership Right) land. It is the strongest right, hereditary, fulfilled, and as the best land rights compared to other land rights ${ }^{17}$, so the occupancy owner will feel much safer, happy, prosperous, and serene to live in the house without having to think about the constraints of HGB extension. The upgrading of HGB status to HM is regulated by Regulation of the Minister of Agrarian Affairs/Head of National Land Agency Number 1 Of 2010 on Service Standards And Land Regulations and Decree of the Minister of Agrarian Affairs/Head of National Land Agency Number 6 Of 1998 regarding Land Ownership For Land._ ${ }^{18}$

Discusses the right not only related to the word of just right, but also relate to morals, morality, ethics and nature. Rights are interests that are protected by law, while interests are the individual or group demands that are expected to be met. The interests essentially contain the power that is guaranteed and protected by law in

\footnotetext{
13 Ibid.

14 Ibid.

15 Bpn.co.id BPN Akan Bantu Perumnas Mencari Solusi Terkait Permasalahan Hak Pengelolaan http://www.bpn.go.id/BERITA/Siaran-Pers/bpn-akan-bantu-perumnas-mencari-solusi-terkaitpermasalahan-hak-pengelolaan-4395 accessed 04 Mei 2018 at 01.04

${ }^{16}$ Article 35 of Law Number 5 Year 1960 on Basic Regulation of Agrarian Principles (UUPA)

17 Pasal 20 UUPA

${ }^{18}$ Interview with the Land Office Officer (BPN) of Semarang City 5 June 2018
} 
carrying it out ${ }^{19}$. Sudikno Mertokusumo stated that, the right is a legal relationship between the subject of rights and the object of rights, because the relationship obtains legal protection. The right of the Nation encompasses all the land within the territory of the Republic of Indonesia. There is no land as "Res Nullius"20". The subject of the nation's rights is the whole of the people of Indonesia throughout the united period as the Indonesian nation, the previous generations, present and future generations. There are various kinds of land rights in accordance with their allocation as regulated in Article 16 Paragraph (1) of the Basic Agrarian Law in the form of: Right of ownership, Cultivation Rights, Right to Build, Right to Use, Right to Lease, Right to Open Land, and others ${ }^{21}$. The Right to Manage (HPL) is not stipulated in the articles of the UUPA, but it is contained in the General Elucidation of UUPA Part II. It states that to achieve the purpose of land for the greatest prosperity of the people, the state may grant land to a person or legal entity with a right and their needs, including giving them in management to any business entity/developer to be used for the performance of their respective duties. ${ }^{22}$

In the licensing of a building, we are certainly familiar about the Certificate of Right to Builds or abbreviated as SHGB. HGB is the authority granted by the government or a right earned for the use of a land which does not belong to itself with a period of 30 years at the request of the holder of the right to bind the necessities and circumstances of its buildings and may be extended to a maximum period of 20 years. ${ }^{23}$

It can be interpreted that the SHGB holder is only authorized to use the land for building or other purposes within a certain period of time. Thus, property owners with HGB status only have the building alone, while the land is still state property. Typically, developers or developers use HGB land to develop housing units and apartments. With SHGB we are not directly free in land use because it must be in accordance with the permit. Another goal that conforms to the SHGB criteria is when we plan to have property only in a temporary period. Property with the status of HGB was suitable developed for something commercial tangible. ${ }_{-}^{24}$

Certificate of Ownership (SHM) is the highest or strongest certificate of rights to a land. SHM is a type of certificate whose holder has full power as the owner of the land in an area with a certain area listed in the letter with an unlimited time. Accordingly, the certificate holder listed in the letter becomes the sole owner without any interference and possible ownership of the other party. ${ }_{-}{ }^{25}$

\footnotetext{
${ }^{19}$ Darwin Ginting 2010 Hukum Kepemilikan Hak Atas Tanah Bidang Agribisnis: Hak Menguasai Negara dalam Sistem Hukum Pertanahan Indonesia Ghalia Indonesia Bogor p. 59

${ }^{20}$ Res nullius is a Latin term from Roman law. Res nullius is also used in international law: states may take unpublished territorial powers and gain power when one of its inhabitants enters the territory. (https://id.wikipedia.org/wiki/Res_nullius)

${ }^{21}$ Boedi Harsono Op. Cit. p. 267 and 271

22 Bpn.co.id Loc. Cit

23 Lamudi.co.id Perbedaan Hak Guna Bangunan Dengan Hak Milik http://www.lamudi.co.id/journal/perbedaan-hak-guna-bangunan-dengan-hak-milik/ accessed on 27 April 19.26 WIB

${ }^{24}$ Ibid

${ }^{25}$ Ibid
} 
Volume 5 Issue 3, September 2018

Classification Comparison of Ownership Rights \& Right to Builds

\begin{tabular}{|l|l|l|}
\hline Category & Ownership Rights (HM) & Right to Builds (HGB) \\
\hline $\begin{array}{l}\text { Subject of Land } \\
\text { Right }\end{array}$ & $\begin{array}{l}\text { 1. Indonesian Citizen } \\
\text { 2. Legal bodies under } \\
\text { certain conditions } \\
\text { (Government Regulation } \\
\text { Number 38 Of 1963 on the } \\
\text { Appointment of Legal } \\
\text { Entities That Ownership of } \\
\text { Land Ownership. }\end{array}$ & $\begin{array}{l}\text { 1. Indonesian Citizen } \\
\text { 2. Legal entities established under } \\
\text { Indonesian law and domiciled in } \\
\text { Indonesia. }\end{array}$ \\
\hline $\begin{array}{l}\text { Characteristic of } \\
\text { Land Right }\end{array}$ & $\begin{array}{l}\text { Strongest and most fulfilled, } \\
\text { can be switched and } \\
\text { transferred to other parties. }\end{array}$ & $\begin{array}{l}\text { Can switch and transfer to other } \\
\text { parties. }\end{array}$ \\
\hline $\begin{array}{l}\text { Giving of Land } \\
\text { Right }\end{array}$ & $\begin{array}{l}\text { For a residence, full power } \\
\text { over the land and buildings } \\
\text { that are above it. }\end{array}$ & $\begin{array}{l}\text { To establish and own a building } \\
\text { on land that is not owned by him } \\
\text { (land owned by other parties), } \\
\text { the property above does not have } \\
\text { to function as a residence, also } \\
\text { for shop, }\end{array}$ \\
\hline $\begin{array}{l}\text { Land } \\
\text { ownership period }\end{array}$ & $\begin{array}{l}\text { Lifetime, hereditary that can } \\
\text { be inherited. }\end{array}$ & $\begin{array}{l}\text { Duration 30 years and can be } \\
\text { extended 20 years. }\end{array}$ \\
\hline Jaminan hutang & $\begin{array}{l}\text { Can be used as debt } \\
\text { collateral with burden of } \\
\text { mortgage. }\end{array}$ & $\begin{array}{l}\text { Can be used as debt collateral } \\
\text { with burden of mortgage. }\end{array}$ \\
\hline
\end{tabular}

\section{Research Methods}

The approach used in this research was the sociological juridical approach, which is to examine how the reaction and interaction that occurs when the implementation of law regulation in the community related to the upgrade of Right of Building (HGB) on the Land of Rights of Management (HPL) Perumnas Become Property Right (HM).

The research specification used in this research was analytical descriptive, that explain or describe the applicable legislation relating to legal theories and practice of implementation of positive law that happened in society. The sample used was purposive sampling. Purposive sampling means that the samples taken were in accordance with the objectives used in research related to the correlation, competence, and capabilities aimed at the relevant parties ${ }^{26}$, such as Citizen Housing Korpri Bangetayu Wetan and Municipal Land Office Officers Semarang.

Various kinds of data used were primary data and secondary data. Data collection techniques used literature study, observation, and interviews. The analytical method used was descriptive qualitative, that was based on the results of collecting data that has been obtained which then compiled and analyzed systematically, after it was interpreted in the form of words and sentences are easy to understand. With analytical

${ }^{26}$ Dr. H. Djauhari S.H. M.Hum Dosen Fakultas Hukum UNISSULA Semarang 
techniques like this, it was hoped to find the core ideas and theories that become the object of the problem to be drawn a conclusion.

\section{Result And Discussion}

Everyone has the right to own the right of private property and the right of property shall not be arbitrarily taken over by anyone (Article 28 letter h paragraph (4) UUDN RI Of 1945).

R.Subekti, argued that the eigendom is the most perfect right of anything. A person who has the right to possess something can do anything with it (selling, pledging, giving, even damaging), provided that it does not violate the law or the rights of others ${ }^{27}$. Thomas Aquinas, states that everyone prefers to obtain something to be his own rather than a common property, because everyone avoids work on something becomes the task of the people. Something will be treated better if the upkeep is left to each person, because if everyone is entrusted with care for all things without a difference, there will be chaos. Conversely, if everyone is given the opportunity to take care of his own, peace will be achieved because everyone is satisfied with what belongs to him. ${ }_{-}^{28}$

The mechanism of upgrading HGB to HM refers to Article 1 paragraph (1) letter a KMNA/KBPN Number 6 of 1998 concerning the Granting of Land Ownership for Residential Land is as follows that the Right to Build or Use Right on the land for the residence belongs to the Indonesian Citizen the extent of $600 \mathrm{M}^{2}$ or less, upon the request being removed and given back to the former holder of the right with the Ownership Right. Land of Right to Build or Right to Use of land for residence belonging to an Indonesian individual of $600 \mathrm{M}^{2} \mathrm{I}$ or less which has expired the period of time and still owned by the former holder of the right, at the request concerned is granted as ownership right to former rights holder. In the grant of such Property, the recipient of the right shall pay the income to the State in accordance with the applicable provisions (Article 1 paragraph (1) and (2) KMNA/KBPN Number 6 of 1998).

To upgrade the status of HGB on HPL Perumnas land into HM, Semarang City Land Office implements the following requirements which are based on Regulation of the Minister of Agrarian Affairs/Head of National Land Agency Number 1 Of 2010 on Service Standards And Land Regulations and Ministerial Decree of Agrarian/Head of State National Land Agency Number 6 of 1998 concerning the Granting of Land Ownership Right For Residential purposes.

- Application forms already completed and signed by the applicant or their proxies on stamp duty;

- Power of Attorney if the application is authorized;

- Copy of identity (ID card, Family Card) of the applicant and authorization if authorized, which has been matched with the original by the counter officer;

- Original proof of land acquisition/Land certificate concerned;

- Recommended of Perumnas HPL Holders;

${ }^{27}$ Landasanteori.com Pengertian Hak Milik Definisi Menurut KUHPerdata Peralihan serta Cara Memperoleh http://www.landasanteori.com/2015/10/pengertian-hak-milik-definisi-menurut.html accessed 01 May 2018, at 22.03

28 Jarot Widya Muliawan Op. Cit. h. 22 (lihat: Imam Soetiknjo 1985 Undang-Undang Pokok Agraria Sekelumit Sejarah Departemen Dalam Negeri. Direktorat Jenderal Agraria Jakarta p. 11 
- Photocopy of Building Permit (IMB) stating that the building is used for residential houses; or Certificate of Village Head/Local Village that the building is used for the residence, if the IMB has not been issued by the authorized institution;

- A copy of the latest SPPT of the PBB (specifically for land of $200 \mathrm{M}^{2}$ or more) that has been matched to the original by the counter officer;

- A statement from the applicant that with the acquisition of the Property to which the application is requested, the concerned will own the Property Right to the land for the residence no more than 5 fields covering a total area of not more than 5,000 $\mathrm{m}^{2}$.

Upon request for registration of such Property, the Head of Land Affairs Office shall issue an order of levy. Fees/tariffs is in accordance with the provisions of the Government Regulations on the types and tariffs on the types of non-tax state revenue (PNBP) applicable to the National Land Agency of the Republic of Indonesia.

\begin{tabular}{|l|l|c|}
\hline \multicolumn{1}{|c|}{ Kind of PNBP } & \multicolumn{1}{c|}{ Unit } & Tariffs \\
\hline $\begin{array}{l}\text { Right to Builds or Right to Use to become Ownership } \\
\text { Right }\end{array}$ & Per unit & Rp 50.000,00 \\
\hline
\end{tabular}

Once the charges are paid in full by the applicant, then the Head of the Land Office registers the removal of the HGB or Right of Use concerned in the land and certificate books and other public lists. The next step is the Head of the Land Affairs Office registers ownership of the former HGB or HP land by making the land book by mentioning this decision as the basis of the Property, and issuing the certificate with a letter made based on physical data used in the registration of HGB or HP.

\section{Constraints often occur in the Improvement of the Status of Right to Build (HGB) on Land Rights Management (HPL) Perumnas Become Ownership Right (HM) (Case Study in Housing Korpri Bangetayu Wetan Semarang and in the Land Office of Semarang City).}

Some people do not know or less understanding of procedures and requirements to upgrade HGB to HM, and those who do not want to mess around because they think that the administrative process in the Land Office is very convoluted, so more often authorized to Notary/PPAT or broker.

On the land proposed (its ownership right) turned out to houseshop, not residence. This is massive happen because the upgrade in rights is not done by checking the location and measurement of land parcels by the Land Office. From the results of interviews to officials of the Semarang city office that the check or measurement is only done if deemed necessary but not mandatory. And from the results of the survey researchers in reality Korpri Housing Bangetayu Wetan Semarang some houses that stand as a shop.

Ignorance of the community relates to IMB (Building permit) applies to one house on a plot of land. The incident of the applicant bought two plots of land for two different houses, and attached to the Land Office of the same IMB could happen also because of the mistake of the Perumnas at the time of handling the IMB. There is also the applicant's incidence of IMB, which after being checked by the officer was IMB is a neighbor's IMB. 
The solution is to conduct further socialization as often as possible to the community through the service of Land Office/BPN and Notary/PPAT. Socialization is important because it is a forgetful human nature, so it must always be reminded. Moreover, it could be that the citizens do not know because during this socialization conducted by the Land Office, they could not attend the socialization, whether because of technological barriers and so forth. Why can involve Notary and PPAT? Since both are general state officials. In addition to having a role on the main duties governed by the legislation, it can also provide extra role for the community and/clients in the form of legal counseling and service delivery for the client who is represented by the notary/PPAT (by authorizing) to do legal action certain on the basis of the scholarship and competence of both positions. Notary and PPAT as a legal profession can certainly provide legal counseling for the clients who come to him for the need to upgrade HGB into HM, as stated in Article 3 Sub-Article Code of Ethics of Official Deed Officer (PPAT): 'Good in order the execution of duties of office or in everyday life, every PPAT is required to provide legal counseling to the public who need his services with the aim that the community realize and live the rights and obligations as citizens and members of the community '. Here the Notary/PPAT provides information about the benefits that the client obtains if he has the status of land in the form of $\mathrm{HM}$ and the process of improving the right of the land can be handled by himself directly to the local Land Office of the Regency/Municipality without having to request the Notary or PPAT. In addition to the citizens can save because they do not need to pay services Notary/PPAT spend budget around Rp 1.000.000,00 and even reach Rp 2.000.000,00, ${ }^{29}$ also self-learning communities in processing the upgrade of rights to the land as part of the Indonesian nation. Furthermore, the physical examination of the dwelling house requested to upgrade its rights as part of the process of increasing property rights for residential property. Because in addition to house potency as a shop, also can occur changes in the physical data of the soil, for example the reduced area of land, so it is no longer appropriate with existing letters.

\section{Closing}

\subsection{Conclusion}

- The mechanism for upgrading HGB on HPL Perumnas land to HM is with the applicant coming to the local Municipal Land Office/District by filling and carrying the following administrative requirements:

- Application forms already filled and signed by the applicant or their proxies on stamp duty;

- Power of Attorney if authorized;

- Copy of identity (ID Card, Family card) of the applicant and authorization if authorized, which has been matched to the original by the counter officer;

- Original proof of land acquisition/Land certificate concerned;

- Recommended of HPL Perumnas Holder;

- Photocopy of Building Permit (IMB) stating that the building is used for residential houses; or certificate from the local village head that the building is

29 Interview with some resource persons (Korpri Housing Residents Bangetayu Wetan Semarang) June 42018 
used for the residence, if the IMB has not been issued by the authorized institution;

- A copy of the last SPPT PBB (specifically for land of $200 \mathrm{M}^{2}$ or more) that has been matched to the original by the counter officer;

- The statement of the applicant that with the acquisition of the Property that the registration is requested, the concerned will own the Property Right to the land for the residence no more than 5 fields covering a total area of not more than $5,000 \mathrm{~m} 2$.

Upon request for registration of such Property, the Head of Land Affairs Office shall issue an order of levy of Rp 50.000,00. After the charges are paid in full by the applicant, then the Head of Land Office registers the removal of the HGB or Right of Use concerned in the land and certificate books and other general listings.

- Constraints are often occurring in the Improvement of the Status of Right to Build (HGB) on Land Rights to Manage (HPL) Perumnas Become Property (HM) (Case Study in Housing Korpri Bangetayu Wetan Semarang and in Land Office Semarang).

- People do not know or less understanding of procedures and requirements to upgrade HGB to HM, and those who do not want to mess around because it assumes that the administrative process in the Land Office is convoluted, so more often authorized to Notary/PPAT, or broker.

- IMB filing errors as a requirement to upgrade property rights.

- On the land proposed Hak Miliknya turned out to stand shop, not home.

\subsection{Suggestion}

- Land Office/BPN also through Notary Public/PPAT held further socialization as much as possible to the community about the upgrade of HGB on land of HPL Perumnas to HM can be done by the citizens independently by taking care of it to the Land Office of the Municipality/Notary/PPAT, or broker. With this action, it can train independence and foster public awareness to have the Right Property as the highest and the strongest right on the land.

- May the municipal/local Land Affairs Office make physical inspection of residential houses requested for the enhancement of their rights as part of the process of increasing property rights for residential houses. Because it can also change the physical data of the plot of land, such as the reduced area of land, so it is no longer appropriate with existing letters. Given Indonesia is a legal country that upholds the value of justice and benefit in the nation and state.

\section{References}

[1] Boedi Harsono 2008 Hukum Agraria Indonesia: Sejarah Pembentukan UndangUndang Pokok Agraria Isi dan Pelaksanaannya Djambatan Jakarta

[2] Bpn.co.id BPN Akan Bantu Perumnas Mencari Solusi Terkait Permasalahan Hak Pengelolaan http://www.bpn.go.id/BERITA/Siaran-Pers/bpn-akan-bantuperumnas-mencari-solusi-terkait-permasalahan-hak-pengelolaan-4395 diakses 04 Mei 2018

[3] Darwin Ginting 2010 Hukum Kepemilikan Hak Atas Tanah Bidang Agribisnis Ghalia Indonesia Bogor 
[4] Jarot Widya Muliawan 2015 Pemberian Hak Milik Untuk Rumah Tinggal Sebuah Kajian Normatif Untuk Keadilan Bagi Masyarakat Buku Litera $\quad$ Yogyakarta

[5] Kartini Mulyadi \& Gunawan Widjaja 2004 Seri Hukum Harta Kekayaan: HakHak Atas Tanah Kencana Jakarta

[6] Keputusan Menteri Negara Agraria/Kepala Badan Pertanahan Nasional Nomor 06 Tahun 1998 Tentang Pemberian Hak Milik Atas Tanah Untuk Rumah Tinggal

[7] Lamudi.co.id Perbedaan Hak Guna Bangunan Dengan Hak Milik http://www.lamudi.co.id/journal/perbedaan-hak-guna-bangunan-dengan-hakmilik/ diakses 27 April 2018

[8] Landasanteori.com Pengertian Hak Milik Definisi Menurut KUHPerdata Peralihan serta Cara Memperoleh http://www.landasanteori.com/2015/10/pengertian-hakmilik-definisi-menurut.html diakses 01 Mei 2018

[9] Peraturan Menteri Negara Agraria/Kepala Badan Pertanahan Nasional Nomor 1 Tahun 2010 tentang Standar Pelayanan Dan Peraturan Pertanahan

[10] Peraturan Pemerintah RI Nomor 24 Tahun 2016 tentang Perubahan Atas Peraturan Pemerintah Nomor 37 Tahun 1998 tentang Peraturan Jabatan Pejabat Pembuat Akta Tanah

[11] Perumnas.co.id Sejarah Perumnas http://www.perumnas.co.id/sejarahperumnas/ diakses 26 April 2018

[12] Properti.kompas.com Pemerintah Gandeng Pengembang Wujudkan Satu Juta Rumah Untuk Rakyat https://properti.kompas.com/read/2018/04/21/200833821/pemerintah-gandengpengembang-wujudkan-satu-juta-rumah-untuk-rakyat diakses 02 Mei 2018

[13] Soetikno 2014 Filsafat Hukum: Bagian I Pradnya Paramita Cetakan Kesebelas Jakarta

[14] Undang-Undang Nomor 5 Tahun 1960 tentang Peraturan Dasar Pokok-Pokok Agraria (UUPA)

[15] Undang-Undang RI Nomor 2 Tahun 2014 tentang Perubahan atas UndangUndang RI Nomor 30 tahun 2001 Tentang Jabatan Notaris (UUJN)

\section{Interview}

[1] Staff of Land Office / BPN Semarang City June 52018

[2] Residents Korpri Housing Bangetayu Wetan Semarang June 4201 